Library and Information Perspectives and Research, 2(1), 30-43, January 2020

ISSN: 2636-7432 (Print) 2636-7440 (Online) Available online at credencepressltd.com

DOI: $\underline{10.47524 / \text { lipr.v2i1.3 }}$

\title{
Students’ use of Federal University Library, Gusau, Nigeria
}

\author{
Charles Nwabueze Chukwuji \\ Readers' Services Librarian \\ University Library, Federal University, Gusau, \\ Zamfara State, Nigeria \\ E-mail: charles.librarian@gmail.com \\ AliyuTsafe Gadanga, $P h D$ \\ University Librarian \\ University Library, Federal University, Gusau, \\ Zamfara State, Nigeria \\ E-mail: agtsafe@yahoo.com \\ Sayudi Sule \\ Technical Services Librarian \\ University Library, Federal University, Gusau \\ Zamfara State, Nigeria \\ E-mail: sulesayudi@gmail.com
}

\begin{abstract}
The purpose of this study was to find out how undergraduates of Federal University Gusau, Nigeria use the library resources The descriptive survey design was used in the study. The population was 3,728 registered library users from the three faculties in Federal University Gusau Library, Nigeria. Proportionate stratified sampling technique was adopted to ensure equal participation of the subgroups (Faculties) in line with their respective population and Krejcie and Morgan (1970) formula table for determining sample size from a giving population was used. Sample population of 346 was arrived at. The instruments for data collection were Students' library registration record and a structured questionnaire. 346 questionnaires were distributed while 328 copies were returned and 282 was duly completed and found usable. The distribution tables for faculty, level and sex were analysed using simple percentage while the research questions were analysed using Mean and Standard Deviation (STD). The criterion mean, 2.50 and above was set for decision. 2.50 and above was considered positive (accepted) on any response to an item, mean score below 2.50 was negative (rejected). Major findings of the study are that Faculty of Science make most use of the Library. It was also found out that 200 and 300 level students make most use of the library. It was also discovered that Male students use the library more than their Female counterpart. Some of the challenges identified include lack of internet access, lack of information retrieval tools, opening hours etc. some recommendations were made including that the Library Management should enhance and provide more information retrieval tools (e.g OPAC, Index to its Serials materials etc.) to discourage users from going direct to the shelf to locate materials.
\end{abstract}

Key words: Analysis, Students, Use of university library, Gusau, Nigeria

\section{Introduction}

University Library is one important type of library that is established to support teaching, learning and research in the University community. They serve both the students and staff (academic and non- academic staff) of their various Universities. University Library is a very important component of the University system, hence, Obiozor, Ogbonna and Anyaegbu (2007) posited that hardly could any University 
exist without a well-established Library. In line with this, the Federal Government of Nigeria (2013), in its National Policy on Education stressed the need for a wellstocked library in our institutions of higher learning and also has as its objectives, acquisition of appropriate skills, abilities and competencies both mental and physical as necessary tools for an individual to live by and contribute positively to the national development.

Towards achieving these goals, libraries in the universities acquire materials/resources that will support teaching, learning and research in the University community. On acquisition of these materials/resources, the Librarians process these materials aimed at giving users quick and easy access to them. These library resources after processing are properly segmented by way of shelving/displaying at the various designated sections/units of the library where they are best suited to serve their intended purposes. Some are to be used directly while some enhances access to others. The various library resources acquired include, books, journals, newspapers, e-resources, encyclopaedias, dictionaries, audio/visual materials, microfilms etc.

Assessment or evaluation of library usage is a very important aspect of library services. According to Emokiniovo and Ogunrombi (2012), time has passed when academic libraries assumed that they were providing excellent services in the face of dwindling economy and increased student's enrolment. The dynamism of knowledge creation/generation and demand in the modern day world coupled with the efforts being made by the library to educate the students on the use of library, calls for periodic assessment of library use. In line with this, Gunasekera (2010) stated that the popularity of the user study in academic library is probably a function of the service- orientation statue of contemporary library philosophy and that Librarians have become increasingly sensitive to their user requirements, hence, user study offers a means of defining a library's clientele, establishing levels of demand for various services and ultimately tailoring those services to meet the interests' of that clientele. As the university is graduating its pioneer students, this study becomes pertinent as it was intended to investigate its students' use of the library.

\section{Brief background of federal university Gusau}

Federal University Gusau is one of the twelve newly approved universities and one of the last three established in February, 2013 as part of the second phase, to enhance access to tertiary education towards striking a balance between access, equity and quality in education. The emphasis by the Federal Government of Nigeria was to have one where such is absent. The University is located in North West Nigeria. It started with three faculties and Seventeen programmes. The faculties are: Faculty of Science, Faculty of Management \& Social Sciences and the Faculty of Humanities\& Education. The University library took off in Zamfara College of Arts and Science (ZACAS) with a Pre-Degree Programme that produced its first set of undergraduates. Then on the $5^{\text {th }}$ January, 2015 academic activities of the university began at the permanent site along Zaria - Gusau road. The library started with about four thousand volumes of books and six hundred journals, largely from donations, but at the moment it has over twenty thousand volumes of relevant and current books and journals, in addition to some thousands of e-resources all available on open access to the university community. 
Charles Nwabueze Chukwuji, Aliyu Tsafe Gadanga and Savudi Sule: Students' use of Federal University Library, Gusau, Nigeria

\section{Statement of the problem}

Library usage is more important than stocking of the library. Use of library resources is very key to the continued existence of any library, because it will encourage the promoters of that library to continue to fund it. Library promoters spend huge sums of money building benefiting structures for their libraries as well as stocking it with needed information materials and facilities. Assessment and evaluation of use of library determines for the decision makers whether the library is meeting up with its objectives or not. In as much as admittance to the library is free, students are still meant to formally register with the library, one of the reason is to be able to monitor the usage of the library which of course will justify or otherwise the continued investment in the library.

Observations and preliminary investigations by the researchers seem to suggest lop-sidedness on the use of Federal University Gusau Library by students of the three faculties. Hence this study seeks to investigate the frequency of use of the library by faculties and level and how they perceive the library resources and services among other things.

\section{Objectives}

The objective of this study is to find out how undergraduates of Federal University Gusau, Nigeria use library resources by faculty. Specifically, the study intends to:

1. Investigate the frequency of use of library resources by the students;

2. Determine the reasons for using the library;

3. Find out how users locate library materials;

4. Find out users' Perception on the library services and facilities
5. Determine the challenges encountered by students in using the library

\section{Research questions}

The following research questions were raised to guide the study.

1. What is the Frequency of Students' use of library?

2. What are the reasons for students' use of library?

3. What are the users' means of locating library materials?

4. What are the users' view on the library services and facilities?

5. What are the challenges encountered by students in using the library?

\section{Literature review}

University libraries are meant to be used and optimally too. Scholars over time have conducted various studies towards assessing or evaluating how university libraries are used by students across different variables. Omehia, Obi and Okon (2008) conducted a study with the aim of establishing the difference among students' characteristics and their use of library services. They discovered that there is a significant difference between students' academic discipline (Science, Social Sciences and Humanities, and Arts) on their use of library services. The analysis showed that students in the Social Sciences and Humanities used the library the most, while students in the arts used it more than science students. According to them their findings is in line with what was earlier reported by Andaleeb and Simmonds (1998), Eskola (1998), and Leckie and Fullerton (1999). Corroborating the above findings, Edom (2008) inhis study of Imo State University library usage during vacation, discovered that the faculty of Social Sciences used the library most with $18(16.8 \%)$ respondents. This is followed by 
Charles Nwabueze Chukwuji, Aliyu Tsafe Gadanga and Savudi Sule: Students' use of Federal University Library, Gusau, Nigeria

Faculty of Humanities with 16 (15\%) while Faculty of Business Administration has 15 (14\%) respondents with $6(5.6 \%)$ belonging to Faculty of Sciences. However, the study of Saliu (2012) at the University of Ilorin showed a contrary result (against Social Sciences) that $75(37.5 \%)$ of his respondents were in the faculty of Science, $61(30.5 \%)$ are in the Social Sciences while $64(32.0 \%)$ of the respondents belongs to the Faculty of Arts. Eluwole, Shorunke and Makinde (2017) discovered from their study of Landmark University Library use, that Collegeof Science and Engineering used the library more than the other colleges with total respondents of $121(65.8 \%)$, this is in line with that of Saliu (2012). The study further showed that Business and Social Sciences records 45 (24.5\%) and College of Agricultural Science the least with 18 $(9.8 \%)$ respectively.

Agboola and Bamigboye (2011) conducted a comparative study on students' level of study and use of library resources in three universities in Nigeria. Students were asked to state the extent of use of library resources according to their level or year of study. At University of Ibadan (UI), the use increases from $100 \mathrm{~L}$ to $500 \mathrm{~L}(14.8 \%$ to $25.5 \%$ ); also, at University of Agriculture, Abeokuta (UNAAB), it increases at each successive year (14\% to $25.9 \%$ ). However, at OlabisiOnabanjo University, Ago-Iwoye, Ayetoro campus (OOU), the case was different as there was a surprising result indicating that $300 \mathrm{~L}$ students used library resources more than 500L students. Urquhart and Rowley cited in Agboola and Bamigboye (2011) conducted a survey on students use of academic libraries, and their result revealed that the fourth year students and above stay longer in the library. Agboola and Bamigboye (2011) revealed that there was no significant relationship between the students' level of study and their use of the library materials in two of the three universities they studied, implying that students can make use of the resources in the library as at when due regardless of their level of study. This is not so, as shown in the study of Eluwole, Shorunke and Makinde (2017) which revealed that 63 $(34.2 \%)$ of their respondents were in 200 level, 52 (28.3) in 300 level, 20 (10.9\%) in 500 level, while 33 (17.9) are in 100 level while 400 level recorded the least usage of the Landmark University's library. Moreover, the study of Eluwole, Shorunke and Makinde (2017) revealed that males used the library more than their female counterparts. The findings showed that out of 200 respondents, $117(63.6 \%)$ were males while females are 67 (36.4\%). Their finding was in line with that of Shorunke, Eluwole and Gbenu (2014) who discovered that little above half of their respondents $51.0 \%$ were males and $49.0 \%$ were females.

According to Ugah (2007), results of his study showed that most of the respondents used the library 2-3 times a week or daily, a good indication of library use. In line with this, Agboola and Bamigboye (2011) found out that in the three universities they studied, 138(15.1\%) used the library 2-3 times daily; 362(39.7\%) said Daily; 132(14.5\%) said occasionally while 280(30.7\%) said When necessary. In their study, Amusa and Iyoro (2013) concluded that their respondents rarely use their institution libraries. The majority of the respondents used the libraries twice weekly and they spend less than one hour during each visit. Also, there are facilities other than the library that the respondents used for their studies. for example, they used their residence hall and apartment most frequently, as well as their College or Faculty libraries, and the Internet café. Gunasekera (2010) in his studies concluded that his findings showed that the undergraduate students are overall satisfied with the library resources, services and 
Charles Nwabueze Chukwuji, Aliyu Tsafe Gadanga and Savudi Sule: Students' use of Federal University Library, Gusau, Nigeria

facilities. But on the other hand, the study also found that library resources and services are not being fully used by the undergraduates either because they are not aware of the resources and services or they do not consider them as being important for their studies.

For Ugah (2007), in his study many reasons were advanced for using the library. The largest number of respondents, 50 (32.6\%), came to read books from the collection, while 42 (27.3\%) came to consult reference materials. This shows that resources are used, even though $20(13 \%)$ came to the library to do course assignments. Oyesiku and Oduwole (in Ugah, 2007) studied academic library use and the investigation revealed that the students used the library most during examinations and to do class assignments. The study further revealed that collections were inadequate to meet users' demands, even when $84.3 \%$ of users are not trained in information retrieval. The study recommends various strategies to market library facilities and services. Oyedum (in Ugah, 2007) examined remedial students' use of library resources of a University of Technology and discovered that students went to the library primarily to read their lecture notes and study for examinations, that the sources most frequently used were textbooks, and that majority of the students "never" borrowed library books.

While Gunasekera (2010) discovered that the main purposes mentioned by the respondents for visiting the library were for reference, for borrowing books and read their notes in the library also more than $90 \%$ of respondents reported that they used borrowing facilities (96\%), photocopy service $(93 \%)$, Nearly $80 \%$ of respondents mentionedthey have not used the Inter Library Loan facility. Another, important finding of the study was that more than $30 \%$ of respondents come to the library for more than three purposes. Edom (2008) discovered that $34(31.8 \%)$ of the respondents used the library during vacation periods to write their research projects/thesis, $10 \quad(9.3 \%)$ respondents indicated going to the library to read newspapers and magazines and to prepare for examinations, while $9(8.4 \%)$ goes to use reference materials, 8 (7.5\%) photocopy documents, 3 (2.8\%) go read their personal notes. None of the respondents, he said indicated going to the library to borrow books because they were on holidays. Ugah (2007) discovered that textbooks are the most frequently-used materials with 98 $(63.6 \%)$, followed by reference materials at 25(16. 2\%).Gunasekera (2010) report showed that (95\%) use reference collection, $(85 \%)$, the palm leaf collection $(80 \%)$, bound periodicals $(79 \%)$ and electronic journal services $(78 \%)$ for their information purposes.

About three quarters $(113,73.4 \%)$ of users studied by Ugah (2007) indicated that they go directly to the shelves to locate material, while $18(11.7 \%)$ asked the library staff. Just 8 (5.2\%) used the card catalogue. According to Ugah this low rate of catalogue use calls for doubt as to whether the library's collections are being fully used. This doubt was confirmed by $129(83.8 \%)$ of respondents who claimed that "sometimes" reading materials were available and was further confirmed when $55(35.7 \%)$ and $43(27.9 \%)$ said they needed assistance in locating materials. Again more than half of the respondents $(84,54.5 \%)$ of Ugah (2007) agrees to always receiving staff cooperation, while $57(37.0 \%)$ sometimes received it. That may explain why users relied more on library staff than on the card catalogue in locating reading materials.According to him while this is commendable, users should learn to use the catalogue. Amusa and Iyoro (2013) also reported that out of the respondents that 
Charles Nwabueze Chukwuji, Aliyu Tsafe Gadanga and Savudi Sule: Students' use of Federal University Library, Gusau, Nigeria

made use of user-librarian collaboration, 236 respondents $(9 \%)$ admitted that the librarians are always ready to assist while only 197 respondents (7\%) considered the library assistance effective.

Half of users $(78,50.6 \%)$ rated library services and facilities as "fair", 40 (26.0\%) rated them "good," $7(4.5 \%)$ as "very good." "Poor" and "very poor" were chosen by $11(7.1 \%)$ and $18(11.7 \%)$ users, respectively. The study of Gunasekera (2010) revealed that most of their respondents (88\%) reported positively on two statements namely, "I can easily locate the resources I need in the library" and "I receive excellent assistance from library staff" with the highmean scores of 1.90 and 2.01 respectively. But the lowest level of agreement on Library orientation programs indicated negative opinion of the respondents regarding user education programs conducted by the library.

Fakandu and Bayero (2014) in their study found out that $25.3 \%$ representing the majority of their respondents indicated that lack of access to internet facilities is a major challenge to their use of library, followed by epileptic power supply with $19.0 \%$ and that the least problem is lack of support from library staff with $12.7 \%$. Lombardo and Condic (in Amusa and Iyoro, 2013) emphasized that the library needs to be a comfortable place otherwise, students will decide to use other alternatives to source the information they need. This remark was borne out of their observation of students' growing dependence on electronic resources and students' lack of understanding that some of the best sources that they could use for research are in print format (Amusa and Iyoro, 2013). On the other hand, Diyoshak (2012) reported that $20.8 \%$ of the respondents indicated challenge in using library catalogue as time consuming and frustrating, $6.3 \%$ said that there are no records of books on the shelves in the catalogues, hence, it easier for them to browse the shelves directly. Respondents in Edom (2008) gave improper shelving of information materials with $28(26.2 \%)$ as the major problem in using Imo State University Library. 18 (16.8\%) indicated noisy environment as a problem; $14(13.1 \%)$ says that lack of information retrieval tools (catalogues, index and bibliographies) as problems as well as inadequate light in the library. Opening and closing hours of the library was indicated as a major problem by $13(12.1 \%)$.

The review above showed that the Social Sciences made more use of the library than other disciplines. The review further showed that there is no level that dominates the use of library. Males were found to use the library more than their female counterpart. There seem to be more users on daily or weekly basis. Other places where students can stay and read including the use of ICT affects the traffic that comes to the library. Many reasons were given as the reason why people use the library, prominent is the traditional one, reading of library books. Users prefer browsing the shelf for their materials than using catalogue cabinet or staff. From the review it was also discovered that a high percentage rated the library services and facilities as being fair. While challenges like poor internet facility, epileptic power supply etc. hinders proper use of university libraries.

\section{Methods}

The descriptive survey design was used in the study. The population was 3,728 registered library users from the three faculties in the university. The study was done at the beginning of 2018/2019 academic session of the University. Proportionate stratified sampling technique was adopted to ensure equal participation of the subgroups in line with their respective population and Krejcie and Morgan (1970) 
Charles Nwabueze Chukwuji, Aliyu Tsafe Gadanga and Savudi Sule: Students' use of Federal University Library, Gusau, Nigeria

formula table for determining sample size from a giving population was used. Sample population of 346 was arrived at. The instruments for data collection were Students' library registration record and a structured questionnaire. 346 questionnaires were distributed while 328 copies were returned out of which 282 were found usable. Respondents were given time and opportunity to complete the questionnaire in the library. While the distribution tables for faculty, level and sex were analysed using simple percentage, the research questions were analysed using Mean and Standard Deviation (STD). The criterion mean of 2.50 and above was set for decision on the research questions. While 2.50 and above was considered positive (accepted) on any response to an item, mean score below 2.50 was negative (rejected). SPSS (version 20) was used for all computations. The response mode used was, Strongly Agree $(\mathrm{SA})=5$, Agree $(\mathrm{A})=4$, Neutral $(\mathrm{N})=3$, Disagree $(\mathrm{DA})=2$, and then Strongly Disagree $(\mathrm{SD})$ $=1$.

\section{Results}

The results of the study are presented in tables.

Table 1: Distribution of respondents by faculty

\begin{tabular}{llrrl}
\hline Faculty & $\begin{array}{l}\text { No. } \\
\text { registered } \\
\text { students }\end{array}$ & $\begin{array}{c}\text { of Copies } \\
\text { questionnaire } \\
\text { distributed }\end{array}$ & $\begin{array}{c}\text { of } \\
\text { returned }\end{array}$ & $\begin{array}{c}\text { Percentage of } \\
\text { Respondents }\end{array}$ \\
\hline Humanities \& Education & $1,231(33 \%)$ & $114(9.2 \%)$ & $81(73 \%)$ & 29 \\
Sciences & $1,810(49 \%)$ & $168(9.2 \%)$ & $138(83 \%)$ & 49 \\
Management \& Soc. Sci. & $687(18 \%)$ & $64(9.3 \%)$ & $63(95 \%)$ & 22 \\
\hline Total & $\mathbf{3 , 7 2 8}$ & $\mathbf{3 4 6}(\mathbf{9 . 2 \%})$ & $\mathbf{2 8 2}(\mathbf{8 1 \%})$ & $\mathbf{1 0 0}$ \\
\hline
\end{tabular}

Table 1 shows the distribution of the respondents across the three faculties. The result showed that Faculty of Sciences got the highest number of questionnaires 168 because it has the highest number of registered users. It is followed by Humanities \& Education 114 and then Management \& Social Sciences 64. Out of the 346 questionnaires that were distributed to them according to their proportionate representation, $81(73 \%)$ were returned by the Faculty of Humanities \& Education, Sciences returned $138(83 \%)$ thereby being the highest respondents and Management and Social Sciences returned 63 (95\%) which is the least response rate. The result therefore, showed that $282(81 \%)$ was returned. The result shows that Faculty of science students made more use of the library than Humanities and Education which in turn used the library more than the Faculty of Management \& Social Sciences. 
Charles Nwabueze Chukwuji, Aliyu Tsafe Gadanga and Savudi Sule: Students' use of Federal University Library, Gusau, Nigeria

Table 2: Respondents' level of study

\begin{tabular}{lll}
\hline Level & $\begin{array}{l}\text { No } \\
\text { respondents }\end{array}$ & $\begin{array}{c}\text { of Percentage of } \\
\text { respondents }\end{array}$ \\
\hline 100 & 43 & 15.2 \\
200 & 95 & 33.7 \\
300 & 95 & 33.7 \\
400 & 49 & 17.4 \\
\hline Total & $\mathbf{2 8 2}$ & $\mathbf{1 0 0} \%$ \\
\hline
\end{tabular}

Field Records (2018/2019 Session)

Table 2 reveals the distribution of the students by their level of studies. The result showed that $43(15.2 \%)$ were in 100 level, 200 and 300 levels are 95 (33.7\%) respectively, while 400 level students are 49 $(17.4 \%)$. This revealed that 100 level students make least use of the library. 200 and 300 level students make most use of the

Table 3: Sex of respondents

\begin{tabular}{lll}
\hline Sex & \multicolumn{2}{c}{$\begin{array}{c}\text { Number of Percentage of } \\
\text { respondents }\end{array}$} \\
\hline Male & 201 & $71 \%$
\end{tabular}

Female $81 \quad 29 \%$

Total $282 \quad \mathbf{1 0 0} \%$

Field Record (2018/2019 Session)

From Table 3, the distribution of the respondents by their sex shows that there are more Males, 201 (71\%) than Female's 81 (239\%) response rate. library. This is perhaps because they have settled at the midpoint having overcome the pressure associated with fresh man activities and final year activities. However, one would have expected 400 level students to make most use of the library as they should be reading seriously for their degree examinations.
Research question one: What is the frequency of Students' use of library?

Table 4 provides the data that answer this question 
Charles Nwabueze Chukwuji, Aliyu Tsafe Gadanga and Savudi Sule: Students' use of Federal University Library, Gusau, Nigeria

Table 4: Frequency of use of library

\begin{tabular}{llccl}
\hline Frequency & F & Mean & Std & Decision \\
\hline Daily & 216 & 3.75 & 1.482 & Accepted \\
Once a week & 201 & 2.51 & 1.316 & Accepted \\
$\begin{array}{l}\text { 2-3 times a } \\
\text { week }\end{array}$ & 253 & 3.66 & 1.452 & Accepted \\
$\begin{array}{l}\text { Once a month } \\
\text { 2-3 times }\end{array}$ & 213 & 2.16 & 1.204 & Rejected \\
$\begin{array}{l}\text { Monthly } \\
\text { Never used the }\end{array}$ & 230 & 2.28 & 1.168 & Rejected \\
Library & 225 & 2.11 & 1.036 & Rejected \\
\hline
\end{tabular}

Table 4 above shows the frequency of usage of the university library by the students. A total of 216 of the respondents with the highest mean score of 3.75 indicated that they used the library daily, 201with mean score of 2.51 use the library once a week, the highest respondents of 253 with a mean of 3.66 used the library 2 to 3 times a week. The first 3 had mean score of above 2.50 set for decision and were therefore accepted. Thus they use the university library regularly. On the other hand, the last three items of once a month, 2 to 3 times monthly and never used the library had 213 (2.166 mean), 230 (2.28 mean) and 225 (2.11 mean) respectively. Their mean scores are below the decision score of 2.50 and are therefore rejected.

Research question two: What are the reasons for Students' use of library resources?

This research question is answered with the data in Table 5.

Table 5: Reasons for using the library

\begin{tabular}{llcll}
\hline Reasons & N & Mean & STD & Decision \\
\hline To borrow library books & 230 & 3.44 & 1.387 & Accepted \\
To read library books & 250 & 4.52 & .807 & Accepted \\
$\begin{array}{l}\text { To consult Reference Materials } \\
\text { To read }\end{array}$ & 229 & 4.16 & .983 & Accepted \\
Newspapers/magazines & 219 & 2.69 & 1.307 & Accepted \\
$\begin{array}{l}\text { To do class assignment/term } \\
\text { paper }\end{array}$ & 244 & 4.27 & .942 & Accepted \\
To photocopy library materials & 225 & 3.16 & 1.368 & Accepted \\
To read Journal articles & 200 & 2.99 & 1.343 & Accepted \\
To read my lecture notes & 243 & 4.41 & .955 & Accepted \\
To use e-resources & 205 & 3.31 & 1.353 & Accepted \\
\hline
\end{tabular}

Table 5 reveals reasons the students use the university library. The table indicates that 'to read library book' attarcted the highest responses of 250 and highest mean score of 
Charles Nwabueze Chukwuji, Aliyu Tsafe Gadanga and Savudi Sule: Students' use of Federal University Library, Gusau, Nigeria

4.52 , "to do class assignment 244 and mean of 4.27, 'to read my lecture notes' 243 and mean 4.41. While the least response was 219 and mean 2.69 'came to read Newspaper/magazines'. They all had mean score above 2.50 decision rule set for positive/acceptability and were all Accepted.
Research question three: What are the means the students use in locating library materials?

The data in Table 6 are used to answer this question.

Table 6: Means of locating materials

\begin{tabular}{llcll}
\hline Means & $\mathrm{N}$ & Mean & STD & Decision \\
\hline Direct to shelves & 235 & 4.36 & .887 & Accepted \\
Card catalogues & 208 & 3.66 & 1.213 & Accepted \\
Library staff & 204 & 2.84 & 1.312 & Accepted \\
Search engines & 209 & 3.09 & 1.331 & Accepted \\
All of the above & 190 & 3.09 & 1.461 & Accepted \\
\hline
\end{tabular}

On means of locating materials in the library, Table 6 shows that most of the respondents 235 and mean 4.36 locate and retrieve needed library material(s) by going 'Direct to shelves'. This direct retrieval from the shelf could be act of self-efficacy, perhaps gained from the course use of library which they were taught in their 100 level. 'Library staff' 204 and mean 2.844,
'Search engine 209 and mean 3.09. This they use to access e-resources. 190 and mean 3.09 said they use all of the items listed. Since their mean scores were above the 2.50 decision rule for Acceptance, they were all accepted.

Research question four: What are the perception of the Students on library resources and services?

Table 7: Perception on the library's resources and services

\begin{tabular}{|llllll|}
\hline S/N & Responses & N & Mean & STD & Decision \\
\hline 21 & Very good & 221 & 4.07 & 1.018 & Accepted \\
22 & Good & 217 & 4.14 & .840 & Accepted \\
23 & Fair & 193 & 2.87 & 1.537 & Accepted \\
24 & Poor & 208 & 2.16 & 1.139 & Rejected \\
25 & Very poor & 203 & 1.80 & .885 & Rejected \\
\hline
\end{tabular}

Table 7 above shows the students' perceptions on the library's resources and services. 221 with 4.07 mean 'sees the library as being Very good, 217 with the highest mean (4.14 mean) perceives the library to be Good, the least number of respondents 193 has a high mean score of above 2.50 (2.87) perceived the library to be
Fair. The 3 items were accepted because they score mean above 2.50. This shows that the students have positive response on the library resources and services. This is an indication that the library is developing well. However, 208 respondents with mean 2.16 perceives the library resources and services to be Poor and 203 (mean 1.80) said Very 
Charles Nwabueze Chukwuji, Aliyu Tsafe Gadanga and Savudi Sule: Students' use of Federal University Library, Gusau, Nigeria

poor. The Two views are negative because their mean score is below the 2.50 decision rule for positive and acceptance and were therefore Rejected.

Research question five: What are the challenges faced by students in using the library?

Table 8: Challenges faced in using the Library

\begin{tabular}{llcccc}
\hline S/N Response & N & Mean & STD & Decision \\
\hline 26 & Unarranged shelves & 226 & 2.49 & 1.323 & Rejected \\
27 & Inadequate information materials & 217 & 2.24 & 1.231 & Rejected \\
28 & $\begin{array}{l}\text { Non-borrowing of books by the } \\
\text { Library }\end{array}$ & 213 & 3.14 & 1.506 & Accepted \\
29 & $\begin{array}{l}\text { Inadequate time for the teaching of } \\
\text { use of Library }\end{array}$ & 212 & 3.13 & 1.401 & Accepted \\
30 & Noisy environment & 223 & 2.38 & 1.320 & Rejected \\
31 & Inadequate lighting in the library & 216 & 2.13 & 1.143 & Rejected \\
32 & None co-operation of library staff & 216 & 2.16 & 1.214 & Rejected \\
33 & Improper shelving of materials & 206 & 2.69 & 1.328 & Accepted \\
34 & Inadequate opening hours & 217 & 2.94 & 1.482 & Accepted \\
35 & No Newspaper index & 212 & 2.58 & 1.327 & Accepted \\
36 & Lack of information retrieval tools & 186 & 2.96 & 1.355 & Accepted \\
37 & Inadequate reading tables and chairs & 195 & 2.75 & 1.404 & Accepted \\
38 & Epileptic power supply & 185 & 2.42 & 1.409 & Rejected \\
39 & Lack of internet facilities & 232 & 4.22 & 1.217 & Accepted \\
\hline
\end{tabular}

The above table shows the result of the research question on challenges users faced in using the university library. Some of the major challenges identified include 'lack of internet facilities, 232 (4.22 mean), this situation has however at the time of this analysis taken care of as the university elibrary's internet access has been put in place. 'lack of information retrieval tools, 186 (2.96 mean), No Newspaper index 212 (2.58 mean), Non-borrowing of books by the Library,213(mean 3.14). This service has also commenced. 'Inadequate opening hour' has 217 respondents and 2.94 mean, this has also improved at the moment as the library has extended it's opening hours to 6.pm, and also operating on Saturdays and Sundays. 'Inadequate reading tables and chairs, 195 (mean 2.75). Inadequate time for the teaching of use of Library, 212(mean 3.13) was also identified as a major challenge. This were all Accepted because of their high mean score which are above 2.50 set for decision rule. Item like 'epileptic power supply 185 (2.42 mean), None co-operation of library staff $216 \quad(2.16 \quad$ mean $)$ and 'inadequate information 217 (2.24) were all Rejected as challenges that affects students use of library resources and services. This is because there mean score falls below the 2.50 decision rule. 
Charles Nwabueze Chukwuji, Aliyu Tsafe Gadanga and Savudi Sule: Students' use of Federal University Library, Gusau, Nigeria

\section{Discussion}

One of the major findings of the study is that there are more Faculty of science students who make use of the library, followed by the Humanities and Education and then Management and Social Sciences. This could be as a result of the large population of the science students in the university and not necessarily that they are the most serious students. This finding is in line with that of Eluwole, Shorunke and Makinde (2017) who discovered from their study of Landmark University Library use, that College of Science and Engineering students used the library more than students of other colleges as well as corroborating the earlier study of Saliu (2012) at the university of Ilorin which showed that faculty of science makes more use of the library than other faculties.

Another finding of the study is that 200 and 300 level students make most use of the library. This is perhaps because they have settled at the midpoint in their university career having overcome the pressures associated with fresh man activities and not yet in the final year. However, one would have expected 400 level students to make most use of the library as they should be preparing seriously for their degree examinations. The finding of an earlier survey conducted byEluwole, Shorunke and Makinde (2017) which revealed that 200 level and 300 level students use the library the most is in line with the present study.

It was also discovered from this study that male students make most use of the library than the female. It is an indication that males devote more time to their studies than their female counterpart. This is in line with the findings of Eluwole, Shorunke and Makinde (2017) which revealed that males use the library more than their female counterpart. This finding they say are in line with that of Shorunke, Eluwole and Gbenu (2014) which revealedthat little above half of their respondents were males.

On research question one which is on the frequency of use, the finding revealed that students use the library more on Daily and Weekly basis. They used the library 2 to 3 times a week. This is expected and therefore, shows good use of the university library. This finding is in agreement with that of Ugah (2007) which showed that most of their respondents used the library 2-3 times a week or daily. Furthermore, Agboola and Bamigboye (2011) corroborated this when they found out that in the three universities they studied, that the libraries were mostly used 2-3 times daily.

It was discovered from research question two that most of the library users go to read library book, do class assignment, read their lecture notes and just few go to read Newspaper/magazines. This is expected as the library goes all out to bridge the gap between the haves and have-nots as far as information resources are concerned. It avails the user the right environment to study. The finding of Ugah (2007) agrees that library resources are used by the students in that order.

Research question three, on the means students use to locate needed library materials. Indicated that they locate and retrieve needed library material(s) by going Direct to the shelves. This direct retrieval from the shelf could be act of self-efficacy and this act could affect optimal utilization of available library resources as it will waste users' time and could not afford them the opportunity of seeing other relevant materials contained in the library catalogue. This finding is in line with the discovery of Ugah (2007) which shows that majority of the students go directly to the shelves to locate materials. 
Charles Nwabueze Chukwuji, Aliyu Tsafe Gadanga and Savudi Sule: Students' use of Federal University Library, Gusau, Nigeria

The finding of research question four shows that the students' perception on library resources and facilities is positive. This is an indication that the library, despite its young age is being growing well. This is in agreement with the findings of Gunasekera (2010) which show that the undergraduate students they studied are overall satisfied with the library resources, services and facilities of the library they studied.

The findings of research question which is on the challenges faced by students in using library resources and facilities, it was found that major challenges students faced in using the university library includes lack of internet facilities. This situation has however at the time of this analysis been taken care of as the university e-library's internet access has been put in place. This challenge however is in line with the findings of Fakandu and Bayero (2014) that $25.3 \%$ representing the majority of their respondents indicated that lack of access to internet facilities is a major challenge to their use of library. Another challenge discovered is Lack of information retrieval tools, this is in line with findings of Edom (2008). No Newspaper index, Nonborrowing of books by the Library was also identified as challenges. However, at the time of this analysis the library has commenced charging \& discharging (borrowing) of books to students. The library started this service first with the staff. Inadequate opening hour was also identified as a challenge; this has also improved at the moment as the library has extended its opening hours by 2 hours as well as operating on Saturdays and Sundays. This finding is also in agreement with that of Edom (2008) where library opening and closing hours was indicated as a major problem. Epileptic power supply, none cooperation of library staff and Improper shelving of materials were not identified as challenges to Federal University, Gusau students' use of library resources and facilities.

\section{Conclusion}

This study discovered that undergraduate students of Faculty of Sciences used the library more than the other faculties; that 200 and 300 level students make most use of the library. Males were found to use the library more than their female counterpart and that there weremore users of the library on daily or weekly basis. Of the reasons that students use the library, reading of library books was most prominent, users prefer going directly to the shelf for their materials than using catalogue cabinet or staff. From the study it was also discovered that a high percentage rated the library services and facilities as being very good. While challenges like poor internet facility, lack of information retrieval tools, No Newspaper index, Non-borrowing of books among others were identified as challenges. Some of the challenges identified as at the time of data collection have been taken care of.

In view of the findings of the study, the following recommendations are made:

1. The library management should enhance and provide more information retrieval tools (e.g OPAC, Index to its Serials materials etc) to discourage users from going direct to the shelf to locate materials.

2. The library management should also consider increasing the library opening hours to at least 8pm.

3. The university management should endeavour to deploy internet signal to the main library.

\section{References}

Amusa, O. \& Iyoro, A. O. (2013). Influence of library environments, instructional programs, and user-librarian collaborations on library use by 
Charles Nwabueze Chukwuji, Aliyu Tsafe Gadanga and Savudi Sule: Students' use of Federal University Library, Gusau, Nigeria

undergraduate students in Nigeria. Chinese Librarianship: an International Electronic Journal, 35. Retrieved from http://www.iclc.us/ cliej/cl35AI.pdf.

Agboola, I. O. \& Bamigboye, O. B. (2011). Students' level of study and user of library resources in Nigerian universities: A comparative study. Library Philosophy and Practice (ejournal). Retrieved from https://digital commons.unl.edu/cgi/viewcontent.cgi?a rticle $=1559 \&$ context $=$ libphilprac .

Diyoshak, R. D. (2012). The use of library catalogue by students in six academic libraries in Plateau State Nigeria. Nigerian Journal of Library, Archival and Information Science, 1 (14), 18-24.

Edom, B. O. (2008). An empirical study of students' use of Imo State University Library. during vacation periods. Nigerbiblios, 19 (1\&2), 1123.

Eluwole, O. A., Shorunke, O. A. \& Makinde, O. O. (2017). A study of the reading habits and library use of students in Landmark University, Kwara State, Nigeria. Journal of Applied Information Science and Technology, 10(3), 6272.

Emokiniovo, K. A. \& Ogunrombi, S. A. (2012). Evaluating the use of faculty libraries in Nigerian universities: A case study of University of Benin. Nigerian Journal of Library, Archival and Information Science, 1 (14), 50-56.

Fakandu, A. M. \& Bayero, D. A. (2014). Accessibility and use of law library resources of Facultyof Law Usman DanfodiyoUniversity Sokoto. African Journal of Information and Knowledge management, 1 (20, 111.

Federal Government of Nigeria (2013).
National Policy on Education. Abuja: NERDC.

Gunasekera, C. (2010). Students usage of an academic library: A user survey conducted at the Main Library University of Peradeniya. Journal of the University Librarians

Association of Sri Lanka. 14, (1), $43-60$.

Krejcie, R. V. \& Morgan, D. W. (1970). Determining sample size for research activities. Educational and Psychological Measurement, 30, 607-610. Retrieved from http:// home.kku.ac.th/sompong/guestspeak ker/KrejcieandMorgan_article.pdf.

Obiozor, R., Ogbonna A. U. \& Anyaegbu, M. (2007). Evaluating the use of university library resources by students and staff of Nnamdi Azikiwe University Awka. Unizik Journal of Research in LIS, 1 (1), 55-62.

Omehia, A. E., Obi, B. B. \& Okon, H. I. (2008). Student characteristics and use of library services in the University of Uyo. Library Philosophy and Practice (e-journal). Retrieved from https://digitalcomm ons.unl.edu/cgi/viewcontent.cgi?artic le $=1176 \&$ context $=$ libphilprac.

Saliu, U. A. (2012). The attitudes of undergraduates towards the use of library: University of Ilorin experience. Journal of Senior Staff Association of National Library of Nigeria, 2 (1), 56-64.

Ugah, A. D. (2007). Evaluating the use of university libraries in Nigeria: A case study of Michael Okpara University of Agriculture, Umudike. Library Philosophy and Practice (e- journal). Retrieved from http://www.webpages.uida ho .edu/ mbolin/ugah2.htm. 